\title{
A história do esporte e do jornalismo esportivo durante a Primeira República portuguesa
}

$\begin{array}{r}\text { History of sports and sports journalism } \\ \text { during the First Republic in Portugal }\end{array}$
Silvana Violdre Goellner

República, desporto e imprensa: o desporto na I República em 100 primeiras páginas (1910-1926)

Francisco Pinheiro e foão Nuno Coelho Lisboa: Edições Afrontamentos, 2012.231 p.

O reconhecimento do esporte como um elemento integrante da identidade nacional pode ser identificado em discursos e práticas de diferentes regimes políticos do passado e do presente. Representado como um espaço no qual se

Silvana Vilodre Goellner é professora associada da Escola de Educação Física da Universidade Federal do Rio Grande do Sul, coordenadora do Centro de Memória do Esporte da mesma instituição e pesquisadora Produtividade em Pesquisa do CNPq (vilodre@gmail.com).

Resenha recebida em 8 de maio e aprovada para publicação em 14 de agosto de 2012 ..

Est. Hist., Rio de Faneiro, vol. 25, no 50, p. 479-482, julho-dezembro de 2012. 
expressam valores edificantes tais como coragem, determinação e abnegação, o esporte teve na construção dessa narrativa um elemento fundamental para sua popularização e afirmação em Portugal e em seus espaços insulares e coloniais.

Tal afirmação se faz notória nas 231 páginas que integram República, desporto e imprensa: o desporto na I República em 100 primeiras páginas (1910-1926). Sua publicação resulta de um extenso trabalho de pesquisa desenvolvido em arquivos e bibliotecas onde os autores mapearam todos os jornais esportivos publicados no período, que somam mais de uma centena. Cumprida essa etapa, os autores escolheram cem primeiras páginas para reproduzir no livro, entendendo-as como "a base para conhecermos a forma como a imprensa desportiva evoluiu e deu conta da evolução do desporto ao longo dos 15 anos e 8 meses que durou a I República” (p. 11).

Seu projeto gráfico é primoroso ao exibir essas páginas como foram publicadas, permitindo assim que cada pessoa faça uma leitura particular e, ao mesmo tempo, ligeiramente influenciada pela narrativa que os autores constroem sobre o esporte e a imprensa esportiva no período analisado. Para além das imagens, a obra é composta de pequenos comentários explicativos sobre cada primeira página publicada, destacando as razões pelas quais foi escolhida entre tantas outras possíveis de ali serem expostas. Apresenta, também, quatro textos introdutórios cujas análises são demarcadas a partir de recortes temporais.

No primeiro texto, intitulado 1910-1913: tempo de esperança e heróis, os autores enfatizam o papel que o jornalismo esportivo teve na divulgação do esporte na I República. Ressaltam o quanto essa prática cultural foi importante para a construção de um novo homem, robusto, enérgico e trabalhador, representação personificada na figura do sportsman, cuja valorização buscava afastar os indivíduos da preguiça, da taberna e dos vícios. Sob o discurso da melhoria da raça, o Estado instituído criava estratégias para a diversificação da prática esportiva, visto que até então dominavam os exercícios de caráter militar e algumas competições restritas à nobreza, tais como as provas de armas (esgrima e tiro), a equitação e a vela. Simpático aos ideais republicanos, o periodismo esportivo promoveu a divulgação de várias modalidades esportivas, entre elas o futebol, um esporte ainda em ascensão no período inaugural da República. Os autores também destacam o registro dos jornais esportivos sobre a digressão de uma equipe portuguesa ao Rio de Janeiro em 1913, fato que marcou o início das disputas futebolísticas entre os dois países.

O segundo recorte temporal é delimitado pelo cenário da Primeira Guerra Mundial, cujas repercussões no contexto esportivo foram evidentes. Com a iminência de Portugal aderir ao conflito, os autores destacam a contribuição dos jornais na divulgação de duas campanhas de caráter nacional: uma delas promovida pela Federação Portuguesa dos Sports e associações esporti- 
vas, que, em apoio ao Ministério da Guerra, manifestavam disponibilidade para atuar na preparação física de jovens portugueses, e outra direcionada para o envio de materiais esportivos aos portugueses aprisionados nos campos alemães, para que pudessem "manter de pé as qualidades físicas e se distraírem depois de horas de trabalho" (p. 92).

Já em 1919-1923: reajustamentos e mudanças, a centralidade das análises empreendidas recai no pós-guerra, quando a discursividade dos jornais focalizou a valorização dos soldados, a glorificação dos heróis esportivos e sobretudo o futebol, que, a partir de então, dominou sua pauta. Destacam-se, ainda, o surgimento dos dois primeiros jornais esportivos no espaço colonial português, ambos lançados em 1922: o Sporting, publicado em Angola com o objetivo de nortear o esporte, mesmo que em Luanda não se pudesse "contar mais de meia dúzia de adeptos" (p. 143), e a Semana Desportiva, de Moçambique, representado como "o paladino da cultura física, preenchendo uma lacuna que a progressiva actividade desportiva de Lourenço Marques vinha tornado cada vez mais visível" (p.152). O jornalismo esportivo português alastra-se à África do mesmo modo que já registrara iniciativas nas ilhas da Madeira (1918) e dos Açores (1917).

O quarto foco analítico proposto recai nos últimos anos da República (1924-1926), identificados pelos autores como os Anos Dourados, nos quais o esporte (sobretudo o futebol) e o jornalismo esportivo viveram um período ímpar de expansão e consolidação. Exemplar dessa afirmação é o aparecimento de 122 novos periódicos esportivos em apenas dois anos, o que por si só evidencia o quanto a adesão ao esporte tornou-se recorrente em todo o país. Esse cenário é alterado no dia 28 de maio de 1926, quando se dá o Golpe Militar que modificaria a história e os caminhos percorridos pelo ambiente republicano, demarcando, inclusive, um novo tom para o jornalismo esportivo nacional. Nas palavras dos autores, "ao contrário do que sucedeu em 1910, em que o novo regime, o republicano, foi acarinhado, agora o momento era de expectativa e hesitação, mostrando um meio desportivo português receoso face à possibilidade de um maior intervencionismo da política no desporto, seguindo o exemplo de outros regimes totalitários europeus" (p. 180).

A relação entre imprensa e esporte é o tema central de República, desporto e imprensa e indica o lugar do qual falam seus autores, cujas publicações anteriores analisam a história tanto da imprensa esportiva quanto do futebol em Portugal. Não é sem razão, portanto, que as análises empreendidas recaem mais sobre o surgimento e desaparecimento dos jornais, e os temas e marcos que estes privilegiaram ao longo da I República, do que propriamente sobre o esporte, suas diferentes conotações, funções e significados no contexto português.

Esta observação não desmerece o trabalho realizado, inclusive porque a obra não se propõe uma análise histórica e sociológica. No entanto, é impossível 
desconsiderar essa ausência quando temos diante de nós a riqueza das fontes primárias compiladas, no caso específico, as cem primeiras páginas dos jornais esportivos. Nelas se pode ler o que está escrito e o que foi silenciado: as perspectivas doutrinárias a orientar os usos do esporte; os preceitos científicos sustentados pela eugenia e pela higiene; o liberalismo a indicar a popularização das práticas corporais e esportivas e, na contramão dessa afirmação, a não garantia de que todos pudessem delas participar; as diferenciações entre o esporte praticado por homens e por mulheres; as disputas de poder no âmbito das instituições esportivas e jornalísticas; as rivalidades clubísticas; a fabricação dos ídolos; a valorização de determinados grupos étnicos; a relação entre Portugal e as colônias africanas; o ufanismo e o nacionalismo, entre tantos outros temas.

Se, por um lado, o livro reafirma uma representação positivada do esporte ao valorizá-lo como fundamental na modernização de Portugal e de seu espaço insular e colonial, por outro, permite desestabilizar tal compreensão na medida em que fornece ao leitor suas fontes de pesquisa permitindo-lhe que faça suas próprias interpretações. Essa possibilidade confere à obra um caráter inovador e plural. Afinal, o que cada pessoa vai ler e ver neste livro está marcado também por aquilo que sua biografia pessoal e o contexto social no qual vive lhe permitem pensar e ver. 